\title{
Cardiac tamponade in juvenile chronic arthritis: report of two cases and review of publications
}

\author{
J Goldenberg, A P Pessoa, S Roizenblatt, R M S Pávoa, M O Hilário, E Atra, M B Ferraz
}

\begin{abstract}
Two cases of systemic juvenile chronic arthritis, complicated by cardiac tamponade and eight previously reported cases are described. The clinical features and radiological, electrocardiographic, and echocardiographic findings were similar for all cases. One patient in this series was treated with corticosteroids and underwent pericardiectomy, dying of sepsis 30 days after surgery. The other patient was also treated with corticosteroids, underwent pericardiocentesis and developed fatal ventricular tachycardia.

Of the 10 cases, only six were successfully treated. Early diagnosis and appropriate treatment are essential for a favourable outcome.
\end{abstract}

Pericarditis in children with chronic polyarthritis was first described by George Frederick Still in $1897 .^{1}$ It is one of the extra-articular manifestations of juvenile chronic arthritis and produces very mild or no symptoms which resolve completely in most arthritic patients. ${ }^{2-5}$

The paucity of symptoms makes the clinical diagnosis of pericarditis very difficult; its incidence varies form 3\% to $9 \%$ among patients with juvenile chronic arthritis. ${ }^{4-9}$ Necropsy studies, however, report a much higher incidence, ranging from $30 \%$ to $50 \%{ }^{48} 10-12 \mathrm{~A}$ high incidence of pericarditis in patients with juvenile chronic arthritis is also reported in echocardiographic studies. ${ }^{13}$ Bernstein et al reported that its incidence in cases of juvenile chronic arthritis, without any clinical or cardiac evidence of pericarditis was $36 \% .^{3}$

Cardiac tamponade is a rare complication of pericarditis in arthritic patients and has been reported in only a few cases of adult rheumatoid arthritis. ${ }^{4814}$ is Even severe pericarditis in patients with juvenile chronic arthritis does not usually evolve to cardiac tamponade. ${ }^{3} 7$ 16-20 Cardiac tamponade in juvenile chronic arthritis was first described by Handforth and Woodbury in 1959,6 and so far there have only been eight reported cases. ${ }^{2} 161721-23$

\section{Case reports}

\section{CASE 1}

A 2 year old boy who had had systemic juvenile chronic arthritis for three months presented with a history of febrile episodes (up to $38^{\circ} \mathrm{C}$ ), recurrent maculopapular rash affecting his face, trunk, and abdomen, dyspnoea, tachypnoea, leg oedema, and weight loss for the past three days. His medical history included upper respiratory infections, asthma, and gastroenterocolitis.

On admission the patient was underweight, very pale, and in poor health (height $81 \mathrm{~cm}$; weight $10 \mathrm{~kg}$ ). Physical examination showed that he had distended jugular veins, hepatosplenomegaly, and leg oedema. His heart rate was 140 beats/minute, respiratory rate $60 /$ minute, blood pressure $90 / 60 \mathrm{mmHg}$, and temperature $40^{\circ} \mathrm{C}$. Poor peripheral perfusion, maculopapular rash over the abdomen and thighs, and generalised lymphadenopathy were also noted. Vesicular breath sounds were bilaterally reduced, and crepitant rales were heard over lung bases. Heart sounds were also reduced, and an $S_{3}$ gallop and a parasternal systolic murmur were detected.

Laboratory findings included: haemoglobin concentration of $85 \mathrm{~g} / \mathrm{l}$; a white cell count of $18 \times 10^{9} / 1$ with $83 \%$ neutrophils; a platelet count of $666 \times 10^{9} / 1$. Protein electrophoresis showed an albumin concentration of $34 \mathrm{~g} / \mathrm{l} ; \alpha_{1}$ globulin of $3.5 \mathrm{~g} / 1 ; \alpha_{2}$ globulin of $12 \mathrm{~g} / \mathrm{l} ; \beta$ globulin of 4.9 $\mathrm{g} / \mathrm{l}$; and $\gamma$ globulin of $14 \mathrm{~g} / \mathrm{l}$. The erythrocyte sedimentation rate (ESR) was $125 \mathrm{~mm} /$ first hour, and the $C$ reactive protein titre was $1 / 20$. Tests for the presence of rheumatoid factor, antinuclear antibodies, and lupus erythematosus cells were negative. Total haemolytic complement (CH50) was 340 IU, six blood cultures were negative, and analysis of the urine yielded normal results.

Chest $x$ ray pictures taken on the day of admission showed an enlarged cardiac silhouette, globular in shape, and pulmonary congestion (fig 1). An electrocardiogram (ECG) showed ST segment abnormalities, $T$ wave

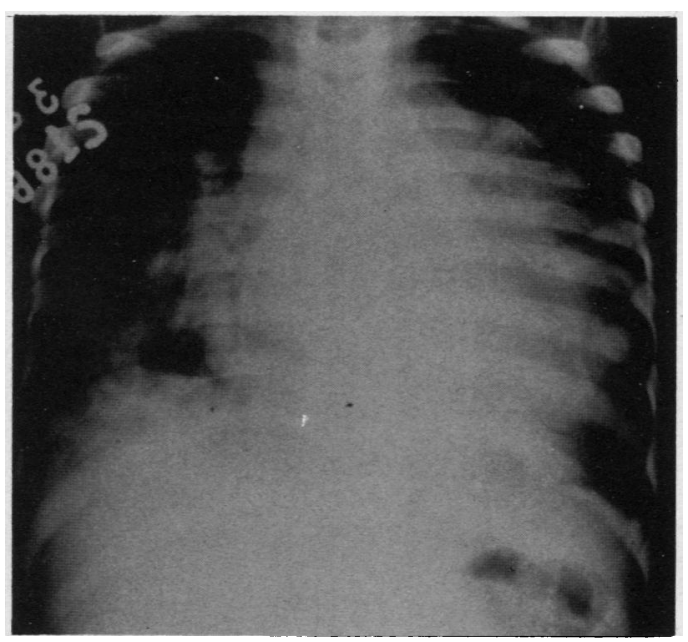

Figure 1: Enlarged heart silhouette and pulmonary congestion on chest $x$ ray picture. 

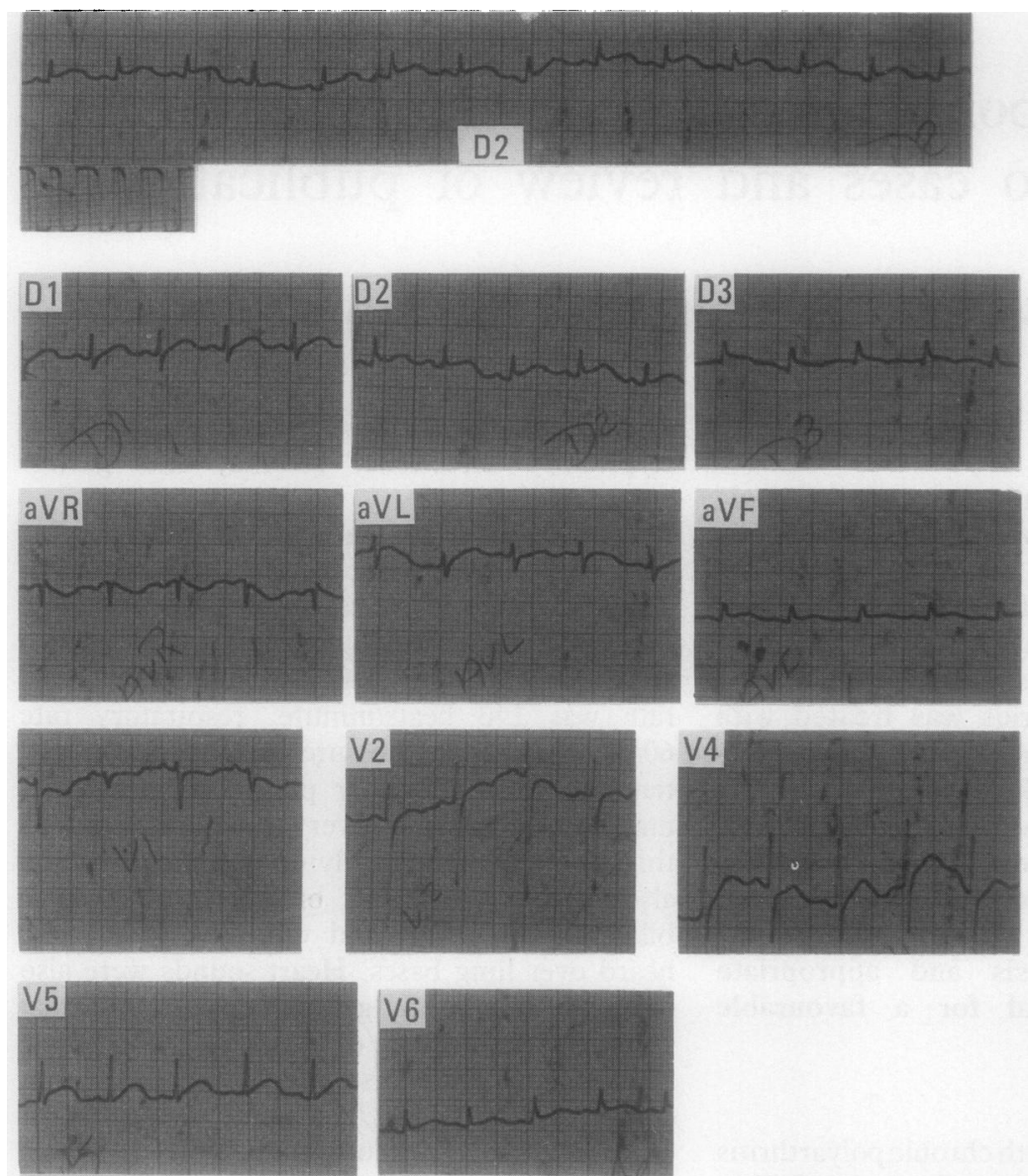

Figure 2: The ECG shows decreased amplitude of $Q R S$ intervals with electrical inversion in $V I$ and $S T$ segment and T wave changes. changes, and a reduced amplitude of QRS intervals in most leads (fig 2). The diagnosis of large pericardial effusion was confirmed by echocardiography (fig 3).

The patient underwent pericardiectomy after $160 \mathrm{ml}$ of serosanguineous fluid had been removed. Chronic non-specific inflammatory reaction in the pericardium was apparent. Plaques of fibrinopurulent exudate, producing adhesions and loculation, recovered the pericardial layers. The pericardium was thickened and ragged. Analysis of pericardial fluid showed a total protein concentration of $39 \mathrm{~g} / \mathrm{l}$, a white cell count of $0.6 \times 10^{9} / 1$ with $41 \%$ neutrophils, and $12.5 \times 10^{9} / 1$ red blood cells. Direct smears and cultures of pericardial fluid failed to show the presence of acid fast bacilli or any other micro-organism. Rheumatoid factor and lupus erythematosus cells were not present in the pericardial fluid. Systemic corticosteroids and antibiotics were given after surgery, but the patient developed sepsis and died 30 days later.

CASE 2

A 3 year old girl with a six month history of systemic juvenile chronic arthritis had had fever, dyspnoea, left knee arthritis, and chest pain for one week. On admission her vital signs were as follows: temperature $38.7^{\circ} \mathrm{C}$; heart rate 136 beats/minute; respiratory rate $64 /$ minute; and blood pressure $50 / 30 \mathrm{mmHg}$. She was dyspnoeic, and her peripheral perfusion was poor. A macular rash was observed over the
Figure 3: Posterior and anterior pericardial effusion detected by echocardiography.

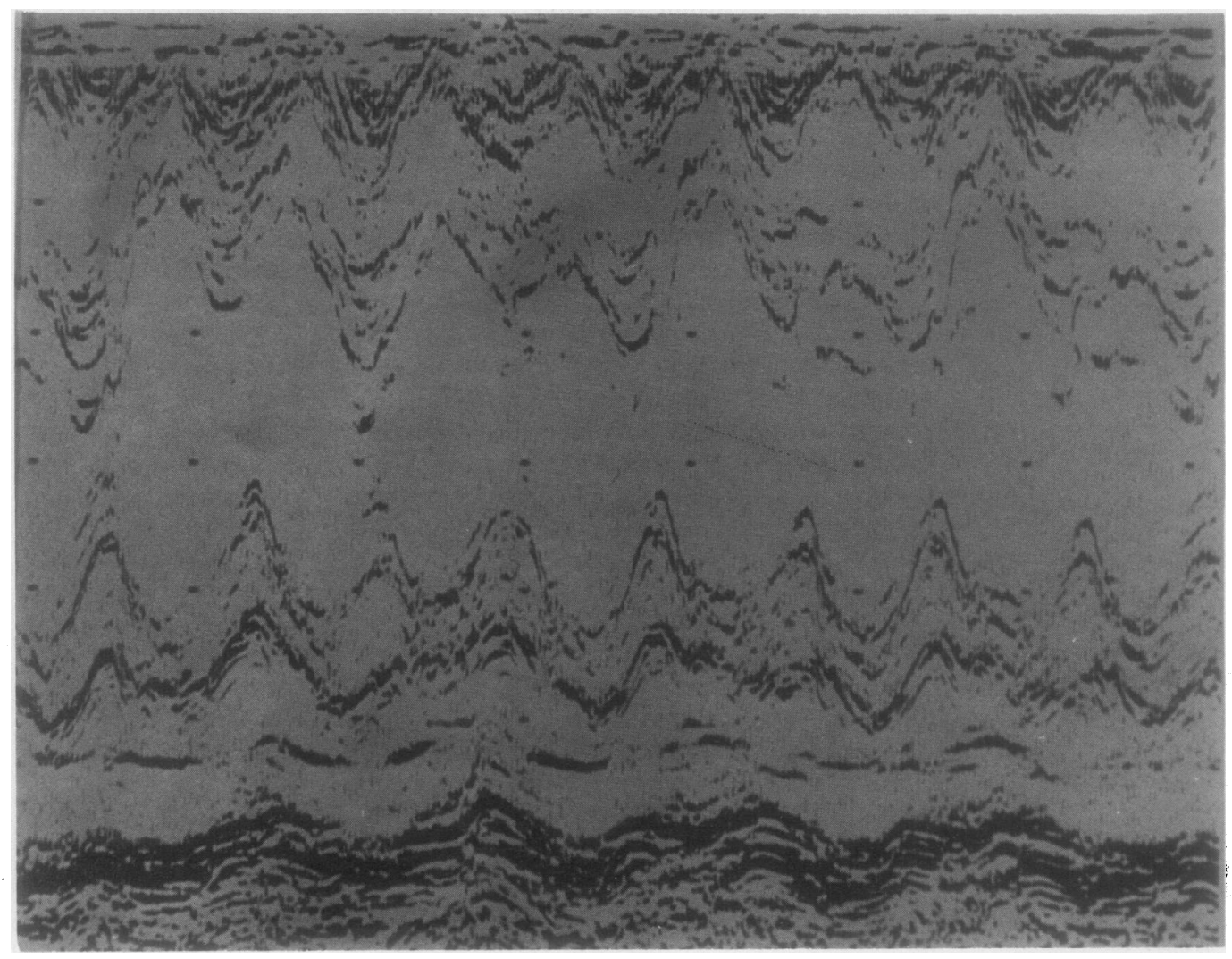


trunk and limbs, and generalised lymphadenopathy was also present. Cardiovascular examination showed arrhythmia, dull heart sounds, and a friction rub. Jugular venous distension was prominent. Crepitant rales were heard below the right costal margin. She also had painful hepatomegaly and left knee arthritis.

Laboratory investigations showed a white cell of $23 \times 10^{9} / 1$ with $87 \%$ neutrophils; a haemoglobin concentration of $90 \mathrm{~g} / \mathrm{l}$; the erythrocyte sedimentation rate was $50 \mathrm{~mm} /$ first hour. Tests for the presence of rheumatoid factor, antinuclear antibodies, $\mathrm{CH} 50$, analysis of the urine, and six blood cultures yielded normal or negative results.

An enlarged cardiac silhouette and pulmonary congestion were shown by the $x$ ray pictures taken on admission. An electrocardiogram showed atrioventricular block of first and second degree associated with junctional escapes, as well as ST segment and $T$ wave abnormalities (fig 4). The patient was given systemic prednisone (2 $\mathrm{mg} / \mathrm{kg} /$ day $)$ and salicylates (100 mg/kg/day).

Cardiac tamponade was confirmed by echocardiography, and pericardiocentesis was performed after $460 \mathrm{ml}$ of serosanguineous fluid had been removed. The analysis of the aspirate
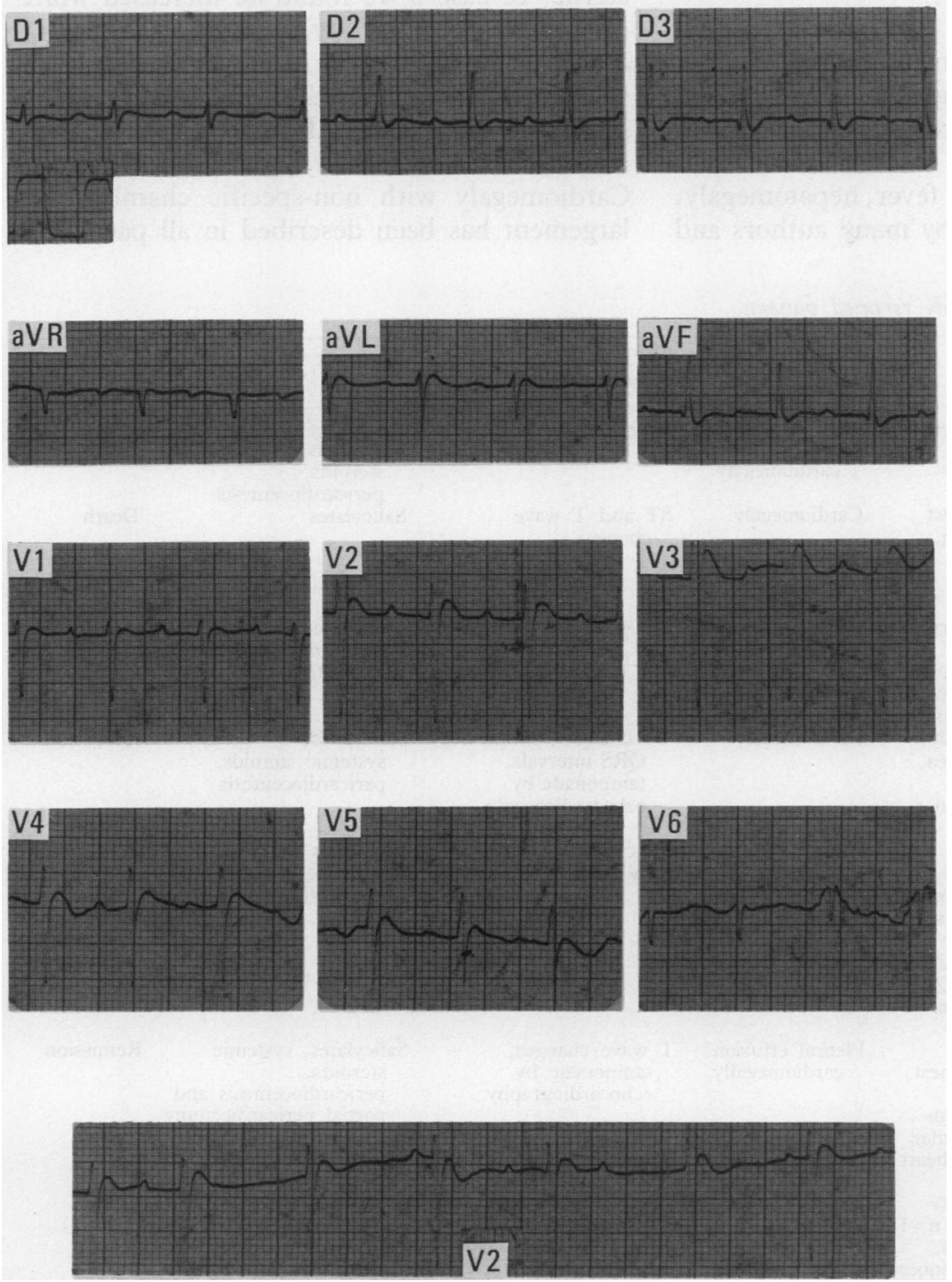

Figure 4: First degree AV block with periods of second degree AV block and junctional escapes plus $S T$ segment and $T$ wave changes. showed a total white cell count of $16 \times 10^{9} / 1$, with $94 \%$ neutrophils. No micro-organisms were found in the fluid. Pericardial biopsy specimens showed a non-specific chronic inflammatory reaction.

While undergoing pericardiocentesis the patient developed ventricular tachycardia and died.

\section{Discussion}

Pericarditis is a well known sign of juvenile chronic arthritis, ${ }^{45}$ especially in its systemic form. Although it usually produces few or no symptoms, pericarditis can be complicated by haemopericardium, ${ }^{24}$ constriction, ${ }^{20}$ and cardiac tamponade. The latter seems to be rare. ${ }^{216} 17^{21-23}$ In contrast, this event seems to be more common in adults with classic rheumatoid arthritis. ${ }^{418} 192425$

The first description of cardiac tamponade in juvenile chronic arthritis was given by Handforth and Woodbury in $1959 .{ }^{21} \mathrm{~A} 16$ year old girl had had systemic juvenile chronic arthritis for six years, when she developed cardiac tamponade. Pericardiocentesis was performed and $110 \mathrm{ml}$ of serosanguineous fluid were removed, with a subsequent noticeable improvement in her condition. The fluid contained numerous neutrophils and was sterile. Subsequently, dyspnoea returned and the patient died as a result of cardiac tamponade, which was confirmed at necropsy.

In a study of aetiological disorders associated with pericarditis in children, Nadas et al found five cases of rheumatoid pericarditis, one of whom died owing to cardiac tamponade. ${ }^{16}$ At necropsy $300 \mathrm{ml}$ of serosanguineous pericardial fluid were drained from the pericardial space.

The first case of cardiac tamponade successfully treated by pericardiocentesis was described by Sharf $e t a l .{ }^{17} \mathrm{~A} 14$ year old girl with a six year history of juvenile chronic arthritis developed cardiac tamponade and underwent pericardiocentesis. Viscous fluid $(350 \mathrm{ml})$ was removed, and she was given an intrapericardial injection of methylprednisolone. The analysis of the pericardial fluid showed a low concentration of glucose, a white cell count of $5 \cdot 2 \times 10^{9} / 1$ with 94\% neutrophils, and no micro-organisms. Majeed et al reported a case of juvenile chronic arthritis and cardiac tamponade sucessfully treated by pericardiocentesis and systemic corticosteroids in $1978 .^{2}$ The pericardial fluid showed a low concentration of glucose and was sterile.

In 1981 Yancey et al described three cases of systemic juvenile chronic arthritis and cardiac tamponade, two of which were given prednisone and underwent pericardiocentesis. ${ }^{22}$ None had constrictive pericarditis after two years and five months of follow up. The pericardial fluid in one of these cases showed a normal concentration of glucose and was sterile in two cases. In 1984 Alukal et al studied 220 cases of juvenile chronic arthritis and found evidence of acute pericarditis in eight and cardiac tamponade in one. ${ }^{23}$ Pericardiocentesis was performed and prednisone was given. Subsequently, a partial pericardiectomy was carried out and $50 \mathrm{ml}$ of sero- 
sanguineous fluid were drained from the pericardial space, with an improvement in symptoms.

In our series of 130 children with juvenile chronic arthritis followed up for five years (33\% of cases with systemic juvenile chronic arthritis) six had clinical evidence of pericarditis and two had evidence of cardiac tamponade. One of these patients underwent pericardiectomy but died of sepsis. The other patient underwent pericardiocentesis, but developed ventricular tachycardia and died. Ventricular tachycardia as a complication of pericardiocentesis has been already reported. ${ }^{17} 25$

The two patients reported here and the six previously reported cases had cardiac tamponade and systemic juvenile chronic arthritis. This is not surprising because pericarditis occurs most commonly in systemic juvenile chronic arthritis. The six girls and two boys with cardiac tamponade previously reported were between 3 and 4 years old; our patients included a boy aged 2 and a girl aged 3 (table).

The signs and symptoms of our patients at the time of cardiac tamponade are summarised in the table and are consistent with those previously reported. Chest pain is a rare symptom in systemic juvenile chronic arthritis and should alert the physician to the possibility of pericarditis. This symptom was present in one of our patients.

The physical findings were also consistent with those previously reported (table). Jugular distension and pulsus paradoxicus were present in both cases, and pericardial friction rub was present in one case.

By the time of diagnosis, fever, hepatomegaly, and arthritis were found by many authors and also observed by us (table), suggesting systemic flare-up of juvenile chronic arthritis with concomitant cardiac tamponade.

Laboratory findings in our patients were similar to those found in patients with systemic juvenile chronic arthritis ${ }^{21-23}$ and included the following: anaemia, leucocytosis, thrombocytosis, increased ESR. Positive antinuclear antibodies $(1 / 160)$ were found in only of the previously reported cases. ${ }^{22}$ In our series rheumatoid factor, antinuclear antibodies, and lupus erythematosus cells were not present, and $\mathrm{CH} 50$ was within the normal range.

The analysis of pericardial fluid is a valuable aid to diagnosis. A decreased concentration of glucose has been described in pleural fluid ${ }^{26}$ and in pericardial fluid. ${ }^{27}$ These findings, in the absence of acid fast bacilli and bacteria, have been considered to be suggestive of a rheumatoid aetiology. Franco et al also described increased concentrations of $\gamma$ globulins and lactic acid dehydrogenase activity in pericardial fluid. ${ }^{8}$ Ball observed $\gamma$ globulin complexes in rheumatoid pericardial fluid in $1975,{ }^{14}$ and the absence of these complexes in serum suggests their local production in the pericardial space.

In case 1 of our series pericardial fluid contained $0.6 \times 10^{9}$ white cells with $41 \%$ neutrophils, red blood cells $12.5 \times 10^{9} / 1$ and it was sterile. In case 2 we found an increased white cell count $\left(16 \times 10^{9} / 1\right.$ with $94 \%$ neutrophils), although the pericardial fluid was sterile. Nonspecific chronic pericarditis was confirmed by biopsy in both cases. Diagnostic studies included chest $x$ rays, ECG, and echocardiograms. Cardiomegaly with non-specific chamber enlargement has been described in all paediatric

Data on two cases presented in this paper and eight previously reported patients

\begin{tabular}{|c|c|c|c|c|c|c|c|}
\hline Reference & $\begin{array}{l}\text { Sex/Age } \\
\text { (years) }\end{array}$ & $\begin{array}{l}\text { Type of } \\
\text { juvenile chronic } \\
\text { arthritis }\end{array}$ & Clinical findings & $\begin{array}{l}\text { Chest } \\
x \text { ray }\end{array}$ & $\begin{array}{l}\text { ECG or } \\
\text { echocardiography }\end{array}$ & Treatment & Outcome \\
\hline $\begin{array}{l}\text { Handforth } \\
\text { Woodbury, } \\
1959^{21}\end{array}$ & Girl 6 & $\begin{array}{l}\text { Systemic } \\
6 \text { years }\end{array}$ & $\begin{array}{l}\text { Fever, arthritis, } \\
\text { dyspnoea, pulsus } \\
\text { paradoxicus }\end{array}$ & $\begin{array}{l}\text { Pleural effusion, } \\
\text { cardiomegaly }\end{array}$ & & $\begin{array}{l}\text { Salicylates, systemic } \\
\text { steroids, } \\
\text { pericardiocentesis }\end{array}$ & Death \\
\hline $\begin{array}{l}\text { Nadas, } \\
\text { Levy, } \\
1961^{16}\end{array}$ & Girl 4 & $\begin{array}{l}\text { Initial } \\
\text { episode of } \\
\text { juvenile } \\
\text { chronic } \\
\text { arthritis }\end{array}$ & $\begin{array}{l}\text { Hepatomegaly, chest } \\
\text { pain, tachypnoea, } \\
\text { friction rub }\end{array}$ & Cardiomegaly & $\begin{array}{l}S T \text { and } T \text { wave } \\
\text { changes }\end{array}$ & Salicylates & Death \\
\hline $\begin{array}{l}\text { Sharf, } \\
\text { Levy, } \\
\text { Benderly, } \\
\text { Nahir, } \\
1976^{17}\end{array}$ & Girl 14 & 6 years & $\begin{array}{l}\text { Arthritis, hepatomegaly, } \\
\text { gastrointestinal } \\
\text { bleeding, chest pain, } \\
\text { jugular distension, } \\
\text { dull heart sounds }\end{array}$ & Cardiomegaly & ST segment changes & $\begin{array}{l}\text { Ibuprofen, } \\
\text { pericardiocentesis with } \\
\text { local steroid injection }\end{array}$ & Remission \\
\hline $\begin{array}{l}\text { Majeed, } \\
\text { Kvasnicka, } \\
1978^{2}\end{array}$ & Girl 4 & $\begin{array}{l}\text { Systemic } \\
1.5 \text { years }\end{array}$ & $\begin{array}{l}\text { Fever, hepatomegaly, } \\
\text { arthritis, dyspnoea, } \\
\text { tachypnoea, } \\
\text { tachycardia, jugular } \\
\text { distension }\end{array}$ & Cardiomegaly & $\begin{array}{l}\text { ST changes, diminished } \\
\text { QRS intervals, } \\
\text { tamponade by } \\
\text { echocardiography }\end{array}$ & $\begin{array}{l}\text { Salicylates, } \\
\text { systemic steroids, } \\
\text { pericardiocentesis }\end{array}$ & Remission \\
\hline $\begin{array}{l}\text { Yancey, } \\
\text { Doughty, } \\
\text { Cohlan, } \\
\text { Athreya } \\
1981^{22}\end{array}$ & $\begin{array}{ll}\text { Girl } & 3 \\
\text { Girl } & 8 \\
\text { Boy } 9\end{array}$ & $\begin{array}{l}\text { Systemic } \\
2 \text { weeks to } \\
9 \text { months }\end{array}$ & $\begin{array}{l}\text { Fever, arthritis, } \\
\text { hepatomegaly, } \\
\text { tachypnoea, dyspnoea, } \\
\text { dull heart sounds } \\
(n=2), \text { pulsus } \\
\text { paradoxicus }(n=2), \\
\text { friction rub }(n=2), \\
\text { jugular distension } \\
(n=3)\end{array}$ & $\begin{array}{l}\text { Pleural } \\
\text { effusion, } \\
\text { cardiomegaly } \\
(n=2)\end{array}$ & $\begin{array}{l}\text { ST changes, tamponade } \\
\text { by echocardiography }\end{array}$ & $\begin{array}{l}\text { Salicylates }(\mathbf{n}=3) \text {, } \\
\text { systemic steroids, and } \\
\text { pericardiocentesis } \\
(\mathbf{n}=2)\end{array}$ & $\begin{array}{l}\text { Remission } \\
(n=3) \\
2 \text { years } \\
\text { and } \\
5 \text { months } \\
\text { follow up }\end{array}$ \\
\hline $\begin{array}{l}\text { Alukal, } \\
\text { Costelo, } \\
\text { Green, } \\
1984^{23}\end{array}$ & Boy 9 & $\begin{array}{l}\text { Systemic } \\
3 \text { years }\end{array}$ & $\begin{array}{l}\text { Fever, arthritis, } \\
\text { hepatomegaly, chest } \\
\text { pain, dyspnoea, } \\
\text { tachypnoea, pulsus } \\
\text { paradoxicus, jugular } \\
\text { distension, dull heart } \\
\text { sounds }\end{array}$ & $\begin{array}{l}\text { Pleural effusion, } \\
\text { cardiomegally }\end{array}$ & $\begin{array}{l}\text { T wave changes, } \\
\text { tamponade by } \\
\text { echocardiography }\end{array}$ & $\begin{array}{l}\text { Salicylates, systemic } \\
\text { steroids, } \\
\text { pericardiocentesis and } \\
\text { partial pericardiectomy }\end{array}$ & Remission \\
\hline This paper & $\begin{array}{l}\text { Boy } 2 \\
\text { Girl } 3\end{array}$ & $\begin{array}{l}\text { Systemic } \\
3 \text { months } \\
6 \text { months }\end{array}$ & $\begin{array}{l}\text { Fever, hepatomegaly } \\
(n=2), \text { arthritis }(n=1), \\
\text { chest pain }(n=1), \\
\text { dyspnoea, tachypnoea } \\
(n=2) \text {, jugular distension } \\
(n=2) \text {, friction rub }(n=1)\end{array}$ & Cardiomegaly & $\begin{array}{l}\text { ST and T wave changes, } \\
\text { diminished QRS } \\
\text { intervals, tamponade } \\
\text { by echocardiography }\end{array}$ & $\begin{array}{l}\text { Salicylates, systemic } \\
\text { steroids, } \\
\text { pericardiocentesis }(n=1) \text {, } \\
\text { pericardiectomy }(n=1)\end{array}$ & $\begin{array}{l}\text { Death } \\
\quad(n=2)\end{array}$ \\
\hline
\end{tabular}


cases reported to date. Three authors reported pleural effusion with concomitant cardiac tamponade. ${ }^{21-23}$ We also observed cardiac enlargement in our series.

The ECG has a limited value as a screening test for pericarditis in juvenile chronic arthritis. Electrical abnormalities include ST segment and $T$ wave changes, 216172223 as well as decreased amplitude of QRS intervals, ${ }^{2}$ which also featured in our patients. The ECG can be normal in rheumatoid pericarditis, as reported by Bernstein $e t a l^{3}$ in 12 of 20 children with pericarditis confirmed by echocardiogram. Yancey reported one case of rheumatoid cardiac tamponade with a normal ECG. ${ }^{22}$

Echocardiography is reported to be the most sensitive non-invasive method for detecting early cardiac disease in adult rheumatoid arthritis. Normier et al detected pericardial effusion by this method in $47 \%$ of patients with no clinical evidence of pericarditis. ${ }^{28}$ Bacon and Gibson also reported a high incidence of pericarditis detected by echocardiography. ${ }^{13}$ Bernstein et al found that diagnosed cases of pericarditis in juvenile chronic arthritis increased in number when patients were evaluated by echocardiography. ${ }^{3}$ They also thought that it was a reliable method for evaluating the extent of pericardial effusion and the degree of myocardial function impairment. ${ }^{3}$ In our series diagnosis of cardiac tamponade was confirmed in this manner.

Differential diagnosis between rheumatoid pericarditis and viral pericarditis can prove difficult. Viral pericarditis frequently follows an upper respiratory infection with a short latent period, an acute onset, and common recurrences. ${ }^{29}$ Other entities associated with pericarditis in children include rheumatic fever, bacterial infection, and, less frequently, benign idiopathic pericarditis. Cardiac tamponade is frequently seen in bacterial pericarditis and is exceptional in idiopathic pericarditis or rheumatic fever. ${ }^{16}$

Because of its rarity the best treatment for cardiac tamponade is difficult to define. To relieve cardiac tamponade pericardiocentesis was performed in six of the eight patients reported in the literature (table), one of whom required additional pericardiectomy. In our series pericardiocentesis was performed in case 2 and pericardiectomy in case 1 .

As for corticosteroids, Sharf et al reported intrapericardial injection of methylprednisolone with satisfactory results. ${ }^{16}$ Systemic use of steroids is controversial. Many authors advocate the use of corticosteroids when the patient develops massive effusion, signs of cardiac disease, or progressive effusion, despite treatment with non-steroidal anti-inflammatory drugs. ${ }^{2}$ 2 $^{21-23}$ In their series Yancey et al reported one case of cardiac tamponade in a 3 year old girl who was successfully treated with salicylates alone. ${ }^{22}$ Nadas and Levi were reluctant to use cortisone treatment routinely. ${ }^{16} \mathrm{We}$ believe that steroids can improve the outcome in rheumatoid cardiac tamponade, but a controlled study would be necessary to establish their real benefit.

1 Still G F. On a form of chronic joint disease in children. Med Chir Tras 1897; 80: 47-50. (Reprinted in Arch Dis Child 1941: 16: 156-9.)

2 Majeed H A, Kvasnicka J. Juvenile rheumatoid arthritis with cardiac tamponade. Ann Rheum Dis 1978; 37: 273-6. cardiac tamponade. Ann Rheum Dis 1978; 37: 273-6.

3 Bernstein B, Takahashi M, Hanson V. Cardiac involvement in juvenile rheumatoid arthritis. $\mathcal{F}$ Pediatr 1984; 85: 313-17.

4 Lietman P S, Bywaters E G L. Pericarditis in juvenile rheumatoid arthritis. Pediatrics 1963; 32: 855-60.

5 Brewer E. Juvenile rheumatoid arthritis-cardiac involvement. Arthritis Rheum 1977; 20 (suppl 2): 231.

6 Calabro J J, Holgerson W B, Sonpal G M, et al. Juvenile rheumatoid arthritis: A general review and report of 100 patients observed for 15 years. Semin Arthritis Rheum 1976; 5: 257.

7 Schaller J, Wedgewood R J. Is juvenile rheumatoid arthritis a single disease? Pediatrics 1972; 50: 940-53.

8 Franco A E, Levine H D, Hall A P. Rheumatoid pericarditis: report of 17 cases diagnosed clinically. Ann Intern Med 1972; 77: 837-84.

9 Gordon D A, Stein J L, Broder I. The extra-articular features of rheumatoid arthritis. Am 7 Med 1973; 54: 445-52.

10 Young D, Schwedel J B. The heart in rheumatoid arthritis. A study of 38 autopsy cases. Am Heart $\mathcal{F} 1944 ; 28$ : $1-23$.

11 Sokoloff $\mathrm{C}$. The heart in rheumatoid arthritis. Am Heart $\mathcal{J}$ 1953; 95: 635-43.

12 Lebowitz W B. The heart in rheumatoid arthritis (rheumatoid disease). A clinical and pathological study of sixty-two cases. Ann Intern Med 1963; 58: 102-23.

13 Bacon P A, Gibson D G. Cardiac involvement in rheumatoid arthritis-An echocardiographic study [Abstract]. Ann Rheum Dis 1972; 31: 426.

14 Ball B V, Schohebloher R, Hester R. Gamma globulin complexes in rheumatoid percardial fluid. Am F Med 1975; 58: $123-8$.

15 Calich A, Bishop R. Pericardial effusion in rheumatoid arthritis. Chest 1973; 64: 778-9.

16 Nadas A S, Levy J M. Pericarditis in children. Am $\mathcal{J}$ Cardiol 1961; 7: 109-17.

17 Sharf J, Levy J, Benderly A, et al. Pericardial tamponade in juvenile rheumatoid arthritis. Arthritis Rheum 1976; 19 $760-2$

18 Stern J B, Sobel J A. Hemorrhagic rheumatoid arthritis. Am f Cardiol 1961; 8: 670 .

19 Nathan M P, Rubinstein H, Rao P B, et al. Pericardial tamponade in rheumatoid arthritis. Fournal of the Medical Society of New Fersey 1980; 77: 111-2.

20 Thadani U, Iveson J M L, Wright V. Cardiac tamponade, constrictive pericarditis and pericardial resection in rheumatoid arthritis. Medicine (Baltimore) 1975; 54: 261-70.

21 Handforth C P, Woodbury J F L. Cardiovascular manifestations of rheumatoid arthritis. Can Med Assoc $\mathcal{F}$ 1959; 80. 86-90.

22 Yancey C L, Doughty R A, Cohlan B A, Athreya B H Pericarditis and cardiac tamponade in rheumatoid arthritis. Pediatrics 1981; 68: 369-73.

23 Alukal M K, Costelo P B, Green F A. Cardiac tamponade in systemic juvenile rheumatoid arthritis requiring emergency pericardiectomy. $\mathcal{I}$ Rheumatol $1984 ; 11: 222-5$.

24 Thomas P, Herse J. A case of rheumatoid arthritis and haemopericardium. Rheumatology and Rehabilitation 1974; 13: $32-6$.

25 Romanoff $\mathbf{H}$, Rozin $\mathbf{R}$, Zoltnick A. Cardiac tamponade in rheumatoid arthritis. Arthritis Rheum 1970; 12: 426-35.

26 Carr D T, Mayne J G. Pleurisy with effusion in rheumatoid arthritis, with reference to the low concentrations of glucose in pleural fluid. Am Rev Respir Dis 1962; 85: 345-50.

27 Latham B A. Pericarditis associated with rheumatoid arthritis. Ann Rheum Dis 1966; 25: 235-41.

28 Nomeir A M, Turner R, Watts E, et al. Cardiac involvement in rheumatoid arthritis. Ann Intern Med 1973; 79: 800.

29 Clayer G G, Taybi H, Riley H D, Simon J L. Pericarditi with effusion in infants and children. $\mathcal{J}$ Pediatr 1970; 63. 265-72. 